\title{
Financial Performance Determinants at the Nigerian Oil and Gas Sector
}

Etim Osim Etim ${ }^{1 *}$, Ihenyen Joel Confidence ${ }^{2}$, Nsima Johnson Umoffong ${ }^{3}$

${ }^{1}$ Department of Accounting Faculty of Business Administration University of Uyo, Nigeria

${ }^{2}$ Department of Accounting and Finance Faculty of Management Sciences Niger Delta University, Yenegoa Bayelsa State, Nigeria

${ }^{3}$ Department of Accounting Faculty of Business Administration University of Uyo, Nigeria

Article History
Received: 06.12 .2020
Accepted: 18.12 .2020
Published: 28.12 .2020
Journal homepage:
https://www.easpublisher.com
Quick Response Code

\begin{abstract}
The study was conducted to examine financial performance determinants at the Oil and Gas sector in Nigeria using listed oil and gas companies. This Investigation is premise on the assertion that the higher the financial performance indicator the better firms will perform, hence the need to confirm the assertion at the Oil and Gas sector which is the anchor of the Nigerian economy. Ex-post facto research design was adopted involving the use of data extracted from published annual account of the sampled oil and gas companies for the period 2012-2018. Data collected were analyzed using descriptive and inferential statistical techniques involving correlation analysis, R-square, adjusted $\mathrm{R}^{2}$, t-statistic, Durbin-Watson (DW) statistic, F-ratio and P-value obtained through multiple regression analysis at 5\% level of significance. The variables of study were Return on Assets (ROA) for financial performance, capital structure (CAS), liquidity (LQ), Size (SZ), Age (AG), Sales Revenue Growth (SRG), Profit Margin (PM) and Tangibility (TAN) as internal variables, and the inflation rate (IFR) and Growth rate of Real Gross Domestic Product (RGDP) as external variables. Result shows four (4) variables CAS $(\beta=0.2998$; $\mathrm{P}$-value $<0.05)$; $\mathrm{SZ}(\beta=0.266$, $\mathrm{P}$-value $<0.05)$; $\mathrm{AG}(\beta=0.267$, P-value $<0.05)$ and PM $(\beta=0.758, \mathrm{P}$-value $<0.05)$ were statistically significant in the model. $\mathrm{R}^{2}$ value of $82.7 \%$ explains the variation in ROA is caused by the internal and external variables of the study. It was recommended that the liquidity of the Oil and Gas companies should be effectively managed by the reduction of excessive current assets as well as disposing of some tangible assets without adversely affecting operations and acquisition of debt instrument such as the debenture instrument.
\end{abstract}

Keywords: Financial Performance, Capital Structure, Liquidity, RGDP.

Copyright (C) 2020 The Author(s): This is an open-access article distributed under the terms of the Creative Commons Attribution 4.0 International License (CC BY-NC 4.0) which permits unrestricted use, distribution, and reproduction in any medium for non-commercial use provided the original author and source are credited.

\section{INTRODUCTION}

The Nigerian economy has been driven by the Oil and Gas sector in the past four and half decades of the country's nationhood. The sector accounted for over $85 \%$ of its foreign exchange earnings, $60 \%$ or more of its GDP, but less than $15 \%$ of its employment rate. The sector is mostly dominated by multinational oil companies with Nigerian oil companies controlling the marginal oil fields following the promulgation of the Nigerian Oil and Gas Industry content Development (NOGICD) Act in 2010. The Act seeks to stimulate the use of Nigerian companies/resources in the award of oil licenses, contracts and projects [1, 2]. The sector in Nigeria has undergone series of reforms aimed at ensuring that the operations of the Oil and Gas companies impact positively on economic growth and development [3].

Sequel to the latent potentials in the sector, the Federal Government of Nigeria has initiated policies and regulatory framework to attract more investment, guarantee increase production capacity and ensure a sustainable environment and sector. How these policies affect operational and financial performance of the companies is an issue that requires empirical investigation

The financial performance of companies is influenced by the nature of business operated, the possible legal, political and environmental regulations, which constitute an essential component of public policy within the organizations' scope of operations. It also defines the risks attached to such business and constitutes a significant factor in the profitability of the firm's operation.

Oil and gas firms are the fastest growing and high-risk companies in Nigeria as indicated by the audited published financial statements; over the years continuously disclosed increasing financial performance. These displayed features are a function of some determinants of variables that stood the sector out among others in the economy. 
Researchers in diverse countries have carried out studies investigating the determinants of financial performance of firms generally other than the oil and gas firms [4-6]. Most of these studies are in the Financial Services Sector, Manufacturing Sector, Pharmaceutical and Allied Chemical Sector among others. They ascertained that the determinants of financial performance are both internal and external in nature. The internal variables include firm's size, firm's age, tangible assets, leverage, capital structure, liquidity, capital adequacy and among others and the external variables are: inflation, Gross Domestic Product (GDP), interest rates, exchange rates, government fiscal policy and among others.

Researchers have also used different financial performance indictors depending on the nature and focus of their studies. Most commonly used indicators include the Returns on Assets (ROA), Returns on Equity (ROE), Returns on Capital Employed (ROCE), Earnings Per Share (EPS), Revenue growth and among others [7-10]. The higher the financial performance indicator, the better the financial performance for the year [11]. The extent this is true for the Oil and gas companies in Nigerian remains sketchy and requires empirical investigation in order to capture the various variables that determine the financial performance of the listed oil and gas companies in Nigeria. The study is in furtherance of this objective.

The specific objectives are:

i. to examine the influence of internal variables (capital structures, liquidity, size, age, sales revenue, growth, profit margin and tangibility) on financial performance of the listed Oil and gas companies in Nigeria

ii. to evaluate the effect of external variables (inflation rate and Real Gross Domestic product) on financial performance of the listed oil and gas companies in Nigeria.

It is expected that the outcome of the findings would benefit operators, and other stakeholders in the sector. Those in the academia will find the study as a relevant reference material for future researches as well as teaching in the fields of accounting, finance, economics and management disciplines.

The rest of the paper is arranged under review of related literature, methodology of study, findings and discussions; conclusion and recommendations

\section{REVIEW OF RELATEd Literature}

The literature review is carried out fewer than three sub headings addressing conceptual issues, the theoretical and empirical reviews.

\section{Conceptual Issues}

The key concepts of study are concisely reviewed under this section.

\section{Concept of Financial Performance}

Financial performance indicates the total attainment of a company in terms of profits, sales, and growth measured on financial basis. It is an important variable for business survival and growth [12]. Financial performance evidence the capability of profits generated in a given time period normally measured on yearly basis by comparing the performance made by the company with those of previous years and those of one or more other companies in the same industry.

Some financial performance indicators or measures include return on Assets (ROA), Return on Equity (ROE), Return on Capital Employed (ROCE), Earnings Per Share (EPS) and among others. Most of these measures of financial performance are determined through computation of relevant ratios such as profitability ratios, efficiency ratios and investors or stock ratios.

Return on Assets (ROA), is computed as total profits divided by the total assets for an accounting period. This ratio measures the capability of the firm to generate profits by utilization of its total assets. It indicates how efficiently the assets of the company are employed to generate returns [8]. A higher ROA means efficient utilization of the company's resources and vice versa.

Return on Equity (ROE) is a measure by how much profit a firm earned compared to the total amount of shareholders' equity reported on the statement of financial position for a period. It is a measure of return for their investment. A company with high return on equity is one that is able to generate cash internally either by retaining earnings or other means [13]. A higher ROE indicates better firm financial performance and rate of return earned on the money invested in the firm by its shareholders.

Return on Capital Employed (ROCE) is calculated as operating profits divided by the total assets less current liabilities of a company for a period of time. The profits considered in computing the ROCE is after deducting operating expenses in the form of distribution costs, administrative expenses, and any other related expenses of the company for the accounting period.

Also, sometimes, an absolute sales or turnover figure is considered as a measure of evaluating financial performance. But it has been argued that the variable is not a good measure of assessment because of ease of manipulation and seasonal variations [14].

For this study, the Return on Asset (ROA) is used as proxy for financial performance indicator. This indicator is used because it is directly a derivation of managements' ability to utilize the assets and a 
performance indicator that gives the overall profitability of a business

\section{Internal Variable that Determine financial Performance}

In this study, the considered internal variables that determine financial performance are capital structure, liquidity, size of firm, revenue growth, profit margin and tangibility.

Capital Structure: The capital structure of an entity is an essential variable for the existence, growth and sustainability overtime. Capital structure is the total combination of sources of financial used by an entity in financing its operations and consists of retained earnings (Reserves), equity and debt finance [15]. Capital structure decision and strategies have a substantial impact on the entities' ability to compete in the competitive business environment, generate profits and returns [16-18]. It includes all of shareholders' fund and debts (both current and non-current) and determines the returns to funds providers.

Liquidity: Liquidity, of an entity, refers to the degree to which current liabilities due for settlement within one accounting year can be settled from the total current assets of the company without affecting the operating processes of the company. Three ratios can basically be computed for a company from liquidity; cash ratio, current ratio and quick or acid test ratio. Liquidity of an entity shows the solvency of the company in a short term and if properly managed, should impact positively on the financial performance.

Company Size: The size of an entity refers to the total assets of the company [8]. The total assets comprises of current and non-current assets, intangible and fictitious assets [16]. There are the resources controlled by an entity and used in generating income. An entity is a going concern and remains in business if it continue to invest and acquire more assets for the purpose of the continuous existence [9].

Age of Entity: Age of a company has to do with the duration of the period the entity has been in operation from its incorporation or the date it listed in the stock market. It is expected that the longer the age of an entity, the greater the market share of the products produced by the entity, and vice versa. When a company's product is being patronized, the financial performance is expected to be positive because of the reputation enjoyed $[19,20]$.

Sales Revenue Growth: Sales growth denotes an increase in revenue arising from sales of products over a period of time [21]. Sales growth is measured using the sales growth ratio and show how fast the firm is growing in terms of its revenue. When sales decrease, the outcome becomes a negative growth. It portrays the rate of growth achieved by a firm in its operation revenue from the previous period. The ratio is expected to be increasing from year to year and should impact positively on financial performance of the entity.

Profit Margin and Financial Performance: Profit margin is one of the profitability ratios used to measure the relationship between profit after tax (PAT) and the revenue for a given period of time. The higher the ratio, the better the financial performance of an entity [13]. This is because, from the Du-point formula for determining Returns on Assets (ROA), profit margin is one of the components used $(\mathrm{ROA}=$ Net income/revenue X Revenue/ asset). Profit margin is determined as profit after tax divided by revenue of a company. There is thus a direct correlation between profit margin and financial performance for entities.

Tangibility: This is concerned with the total non-current assets of the company. Tangible assets are referred to as Property, Plant and Equipment (PPE) of an entity. They are assets acquired for use in the operation of an entity other than for sale and constitute the principal components of income generation and therefore, can affect the financial performance of an entity. Tangibility is calculated as PPE divided by total assets. Investments in non-current assets are a key strategic management decision and due to technological changes, management of companies will always consider the appropriate timing for acquisition and disposal of non-current assets so that operations are not drastically affected, and profitability and financial performance negatively impacted.

\section{External Variables that Determine Financial Performance}

The main external variables considered in the paper that determine the financial performance of companies are inflation and Gross Domestic Product (GDP).

Inflation: The concept of inflation has been defined as a persistent rise in the general price level of goods and services in a country over a long period of time [22]. Inflation has been inherently linked to money supply in an economy and it is a situation when there is a continuous rise in price of goods and services for a longer period of time and not for a shorter period of time. It is measured as the percentage change in the consumer price index (CPI). It represents the cost of living, and is, therefore, more approximate for measuring the welfare of the people. Inflation in an economy may affect the financial performance of companies negatively because of the facts that resource used by companies are purchased from the external environment that takes into consideration the economy situation of the country at a particular period of time [8]. 
Gross Domestic Product (GDP): This is a commonly used measure of economic growth and is defined as an increase in economic performance indicators of any country at a particular period of time. It is the total market value of all goods and services produced in a country for a given time period [23]. When there is economic growth, it is assumed that the financial performance of companies should also improve.

\section{TheORETICAL REVIEW}

We adopt the opened system theory for this study. Opened system theory was initially developed by Ludwig Von Bertanlanffy [24], a biologist but it was immediately applicable across all disciplines. Traditional theorists regarded organizations as closed systems that are autonomous and isolated from outside world. In the 1960s, however, more holistic and humanistic ideologies emerged. Recognizing that traditional theory had failed to take into accounts many environmental; influences that impacted on the organizational efficiency and effectiveness. In the modern time, the opened system theory is embraced by theorists and researchers because of how external environment influence the performance of an entity. The opened system theory considers both internal and external variables that impact and is being impacted by organizational system. These variables include cultural, economic, legal/political, technology and among others.

From the economic perspective, opened system theory considers the variables that can affect the financial performance of oil and gas companies in Nigeria, which are inflation, economic growth, unemployment and among others. In this study, the external variables examined are inflation and gross domestic product. High inflation is detrimental to the financial performance of companies for the fact that it lowers the profitability of companies because of the high cost of raw materials acquired from the external environment [16, 23]. Also, growing economy affect the performance of entities positively because in that period, other economic indicators are maintained at minimum level. Economic growth implies that macroeconomic problems are reduced to the barest by the government in an economy. This theory is relevant to the study because the variables of study are both internal and external in perspective.

\section{EMpirical ReVieW}

The review of previous studies found relevant and related to this study are summarized in this section of the paper in a tabular format considering the author(s), topic of investigation, methodology adopted for the study and main findings:

Table-1: Summary of Empirical Review

\begin{tabular}{|c|c|c|c|c|}
\hline $\mathbf{S} / \mathbf{N}$ & Author(s) & Topic & Methodology & Findings \\
\hline 1. & $\begin{array}{l}\text { Bashir, } \\
\text { Abbas, } \\
\text { Manzoor and } \\
\text { Akram [25] }\end{array}$ & $\begin{array}{l}\text { The factors that } \\
\text { affect firm's } \\
\text { performance: A } \\
\text { study of food sector } \\
\text { of Pakistan }\end{array}$ & $\begin{array}{l}\text { Quantitative research design was adopted } \\
\text { and the type of data used was } \\
\text { panel/longitudinal and collected from } \\
\text { publication of listed companies in Karachi } \\
\text { Stock Exchange for the period of 2005- } \\
2010\end{array}$ & $\begin{array}{l}\text { From the research of the analysis, long } \\
\text { term leverage, size, risk and tangibility, } \\
\text { and non-debt tax shield showed positive } \\
\text { and significant relationships with } \\
\text { Return on Investment (ROI) in food } \\
\text { sector of Pakistan. }\end{array}$ \\
\hline 2. & $\begin{array}{l}\text { Mirza and } \\
\text { Javed [5] }\end{array}$ & $\begin{array}{l}\text { Determinant of } \\
\text { Financial } \\
\text { performance of a } \\
\text { firm: case of } \\
\text { Pakistani Stock } \\
\text { market. }\end{array}$ & $\begin{array}{l}\text { The Researchers examined the } \\
\text { performance of firms and its association } \\
\text { with multiple determinants for } 60 \text { Pakistan } \\
\text { corporate firms listed in Karachi Stock } \\
\text { Exchange for the period of } 2007 \text { to } 2011 \\
\text { using fixed effects model }\end{array}$ & $\begin{array}{l}\text { The results reliably support the } \\
\text { potential association between firm, } \\
\text { financial performance and economic } \\
\text { indicators, corporate governance, } \\
\text { ownership structure, and capital } \\
\text { structure }\end{array}$ \\
\hline 3 & $\begin{array}{l}\text { Omondi and } \\
\text { Muturi [19] }\end{array}$ & $\begin{array}{l}\text { The factors } \\
\text { affecting the } \\
\text { financial } \\
\text { performance of } \\
\text { listed companies at } \\
\text { the Nairobi } \\
\text { Securities exchange, } \\
\text { Kenya. }\end{array}$ & $\begin{array}{l}\text { The researchers adopted exploratory } \\
\text { research design and } 29 \text { listed firms } \\
\text { excluding listed banks and insurance } \\
\text { companies which have consistently been } \\
\text { operating at the Nairobi Securities } \\
\text { Exchange during the } 2006 \text { to } 2012 \text { were } \\
\text { sampled purposive sampling technique } \\
\text { was used }\end{array}$ & $\begin{array}{l}\text { Leverage had a significant effect on } \\
\text { financial performance }\left(\beta_{1}=-0.289, \mathrm{P}\right. \\
<0.05) \text {. Findings showed that liquidity } \\
\text { had a significant positive effect on } \\
\text { financial performance }\left(\beta_{2}=0.296, \mathrm{P}\right. \\
<0.05) \text { company size had a significant } \\
\text { positive effect on financial performance } \\
\left(\beta_{3}=0.489, \mathrm{P}<0.05\right) \text {. The study also } \\
\text { revealed that company age had a } \\
\text { significant on financial performance. } \\
\left(\beta_{4}=0.168, \mathrm{P}<0.05\right) \text {. }\end{array}$ \\
\hline 4 & $\begin{array}{l}\text { Enekwe, } \\
\text { Agu and } \\
\text { Eziedo [6] }\end{array}$ & $\begin{array}{l}\text { The effect of } \\
\text { financial leverage } \\
\text { on financial } \\
\text { performance: } \\
\text { evidence of quoted } \\
\text { pharmaceutical } \\
\text { companies in } \\
\text { Nigeria }\end{array}$ & $\begin{array}{l}\text { The ex-post facto method of design was } \\
\text { adopted by the researchers. The researcher } \\
\text { depended heavily on historical data for the } \\
\text { analyses generated from annual financial } \\
\text { reports of the selected quoted } \\
\text { pharmaceutical companies in Nigeria from } \\
2001-2012\end{array}$ & $\begin{array}{l}\text { From the analysis debt ratio and Debt- } \\
\text { equity ratio had negative effect on the } \\
\text { Return on Assets, while the interest } \\
\text { coverage had a positive effect on the } \\
\text { ROA of the quoted pharmaceutical } \\
\text { companies in Nigeria. However, the t- } \\
\text { statistics calculated for each of the } \\
\text { independent variables were not } \\
\text { statistically significant }\end{array}$ \\
\hline
\end{tabular}




\begin{tabular}{|c|c|c|c|c|}
\hline 5 & $\begin{array}{l}\text { Hassan and } \\
\text { Farouk [26] }\end{array}$ & $\begin{array}{l}\text { Firm attributes and } \\
\text { earnings quality of } \\
\text { listed oil and gas } \\
\text { companies }\end{array}$ & $\begin{array}{l}\text { The researchers adopted multiple panel } \\
\text { regression techniques and data were } \\
\text { collected from the annual reports and } \\
\text { accounts of the firms }\end{array}$ & $\begin{array}{l}\text { The findings revealed that leverage, } \\
\text { liquidity and firms growth has a } \\
\text { significant positive impact on earnings } \\
\text { quality while firm size, institutional } \\
\text { ownership and profitability have a } \\
\text { significant but negative influence on } \\
\text { earnings quality. }\end{array}$ \\
\hline 6 & $\begin{array}{l}\text { Akeem, } \\
\text { Edwin, } \\
\text { Kiyanjui and } \\
\text { Kayode [15] }\end{array}$ & $\begin{array}{l}\text { Capital Structure } \\
\text { and firm's financial } \\
\text { performance: } \\
\text { Empirical study of } \\
\text { manufacturing } \\
\text { companies in } \\
\text { Nigeria }\end{array}$ & $\begin{array}{l}\text { The ex-post facto research was adopted in } \\
\text { the study. The researchers used secondary } \\
\text { data and multiple regression analytical } \\
\text { tool was used to analyze the collected data }\end{array}$ & $\begin{array}{l}\text { From the findings, it was discovered } \\
\text { that capital structure (total debt and } \\
\text { debt equity ratios) were negatively } \\
\text { related to firms performance. }\end{array}$ \\
\hline 7 & $\begin{array}{l}\text { Adeusi, } \\
\text { Kolapo and } \\
\text { Aluko [27] }\end{array}$ & $\begin{array}{l}\text { Determinants of } \\
\text { commercial banks' } \\
\text { profitability: panel } \\
\text { evidence from } \\
\text { Nigeria. }\end{array}$ & $\begin{array}{l}\text { The ex-post facto design was adopted in } \\
\text { the study. Panel data method was used to } \\
\text { analysis time series and cross sectional } \\
\text { data gathered from } 2000 \text { to } 2013 \text { from a } \\
\text { sample of fourteen banks }\end{array}$ & $\begin{array}{l}\text { The findings revealed that assets } \\
\text { quality, management efficiency and } \\
\text { economic growth are the determinants } \\
\text { of commercial banks' profitability. } \\
\text { They were found to be statistically } \\
\text { significant on profitability in both the } \\
\text { fixed effect and random effect models. }\end{array}$ \\
\hline 8 & $\begin{array}{l}\text { Wanjugu } \\
{[20]}\end{array}$ & $\begin{array}{l}\text { The determinants of } \\
\text { financial } \\
\text { performance in } \\
\text { general Insurance } \\
\text { companies in Kenya }\end{array}$ & $\begin{array}{l}\text { The descriptive survey research was } \\
\text { adopted in the study. The sample size for } \\
\text { the study encompassed all the twenty } \\
\text { three (23) general insurance companies in } \\
\text { Kenya from year } 2009 \text { to } 2012 \text {. The } \\
\text { independent variables were leverage, } \\
\text { retention ratio, liquidity, underwriting } \\
\text { risk, equity capital, size, management, } \\
\text { competence index, ownership and age and } \\
\text { return on assets (ROA) as dependent } \\
\text { variables. }\end{array}$ & $\begin{array}{l}\text { From the analysis, it was concluded that } \\
\text { profitability of general insurers in } \\
\text { Kenya was positively and significantly } \\
\text { influenced by leverage, equity, capital, } \\
\text { and management competence index. } \\
\text { Size of the firm and ownership structure } \\
\text { had a negative and significant effect on } \\
\text { performance of general insurers in } \\
\text { Kenya }\end{array}$ \\
\hline 9 & $\begin{array}{l}\text { Olaoye and } \\
\text { Olarewaju } \\
{[8]}\end{array}$ & $\begin{array}{l}\text { Determinants of } \\
\text { Deposit Money } \\
\text { Bank's profitability } \\
\text { in Nigeria }\end{array}$ & $\begin{array}{l}\text { The ex-post facto method of design was } \\
\text { adopted. The data used for the study were } \\
\text { secondary in nature and obtained from } \\
\text { annual audited account and financial } \\
\text { report of banks published in the Nigerian } \\
\text { Stock Exchange fact book. A panel date of } \\
\text { the total fifteen (15) quoted banks } \\
\text { covering a period of nine (9) years, from } \\
2004 \text { to } 2012 \text {, were used. }\end{array}$ & $\begin{array}{l}\text { The results indicated that variation in } \\
\text { ROA that is explained by changes in } \\
\text { both internal and external variables in } \\
\text { the model was } 84.8 \%\left(\text { Adj. } \mathrm{R}^{2} \text { ) }\right.\end{array}$ \\
\hline 10 & $\begin{array}{l}\text { Adesina, } \\
\text { Nwidobie } \\
\text { and Adesina } \\
{[17]}\end{array}$ & $\begin{array}{l}\text { Capital structure } \\
\text { and financial } \\
\text { performance in } \\
\text { Nigeria Banks }\end{array}$ & $\begin{array}{l}\text { The research design adopted for the study } \\
\text { was ex-post facto design. Ten most } \\
\text { capitalized banks were sampled for the } \\
\text { study. Secondary data on equity (EQ), } \\
\text { debt (DB) and annual profits before tax } \\
\text { (PBT) were obtained from the annual } \\
\text { reports for the period } 2005 \text { to } 2012 \text { for the } \\
\text { study }\end{array}$ & $\begin{array}{l}\text { From the analysis, both Equity (EQ) } \\
\text { and Debt (DB) capital were statistically } \\
\text { significant in the model as both } \\
\text { variables indicated positive relationship } \\
\text { with PBT of the sampled Banks. }\end{array}$ \\
\hline 11. & $\begin{array}{l}\text { Iskakou and } \\
\text { Yilmaz [28] }\end{array}$ & $\begin{array}{l}\text { Performance } \\
\text { evaluation of major } \\
\text { integrated Oil and } \\
\text { Gas companies }\end{array}$ & $\begin{array}{l}\text { The study adopted the quantitative } \\
\text { research design along with comprehensive } \\
\text { theoretical background on the global oil } \\
\text { and gas industry. Four (4) international } \\
\text { Oil companies were selected for the study }\end{array}$ & $\begin{array}{l}\text { From the financial ratios computed, all } \\
\text { companies showed relatively good } \\
\text { result on liquidity (LQ) position, } \\
\text { Exxon Mobil corporation had the most } \\
\text { outstanding result on leverage (LV); on } \\
\text { short term asset management (SAM), } \\
\text { most healthy turnover assets } \\
\text { management was observed from Exxon } \\
\text { Mobil corporation; on long term asset } \\
\text { management (LAM), all companies } \\
\text { showed relatively good results; on } \\
\text { profit margin (PM), among the major } \\
\text { companies, Exxon Mobil and Chevron } \\
\text { had showed the most impressive results } \\
\text { relatively to other peer corporations }\end{array}$ \\
\hline
\end{tabular}




\begin{tabular}{|c|c|c|c|c|}
\hline 12 & Cekrezi [16] & $\begin{array}{l}\text { Determinants of } \\
\text { financial } \\
\text { performance of } \\
\text { insurance } \\
\text { companies: A case } \\
\text { of Albania. }\end{array}$ & $\begin{array}{l}\text { The ex-post facto design was adopted. } \\
\text { Depending on data availability, the study } \\
\text { was based on data collected from five } \\
\text { insurance companies which operate in } \\
\text { Albania }\end{array}$ & $\begin{array}{l}\text { Total debt ratio had a negative and } \\
\text { significant relationship to ROA, } \\
\text { tangibility has a positive and significant } \\
\text { relationship to ROA, and size was not } \\
\text { significant determinant of the level of } \\
\text { performance of insurance companies. }\end{array}$ \\
\hline 13 & $\begin{array}{l}\text { Grace, Ann } \\
\text { and } \\
\text { Onodugo } \\
{[21]}\end{array}$ & $\begin{array}{l}\text { Liquidity } \\
\text { management and } \\
\text { profit performance } \\
\text { of pharmaceutical } \\
\text { manufacturing firms } \\
\text { listed in Nigerian } \\
\text { Stock Exchange } \\
\text { (NSE) }\end{array}$ & $\begin{array}{l}\text { The ex-post facto research design was } \\
\text { adopted in the study. The researchers used } \\
\text { secondary sources of data. The multiple } \\
\text { regression analytical tool was used to } \\
\text { analyse the data collected }\end{array}$ & $\begin{array}{l}\text { The findings indicated that liquidity } \\
\text { ratio and profitability of the companies' } \\
\text { studied were significantly and } \\
\text { positively related. The debt ratio and } \\
\text { sales growth ratio had positive but } \\
\text { insignificant impact on profitability of } \\
\text { the firms. }\end{array}$ \\
\hline 14 & $\begin{array}{l}\text { Nwaolisa } \\
\text { and Chijindu } \\
{[29]}\end{array}$ & $\begin{array}{l}\text { Influence of } \\
\text { financial structure } \\
\text { on profitability with } \\
\text { special reference to } \\
\text { oil and gas firms in } \\
\text { Nigeria }\end{array}$ & $\begin{array}{l}\text { The ex-post facto method of design was } \\
\text { adopted. The data for the study were } \\
\text { obtained from the published annual } \\
\text { reports and accounts of ten (10) oil and } \\
\text { gas firms listed on the Nigerian Stock } \\
\text { Exchange (NSE) }\end{array}$ & $\begin{array}{l}\text { The overall result of the study indicated } \\
\text { that financial structure has negative } \\
\text { effect on the profitability of oil and gas } \\
\text { firms in Nigeria }\end{array}$ \\
\hline 15 & $\begin{array}{l}\text { Abubakar, } \\
\text { Sulaiman } \\
\text { and Harunna } \\
{[9]}\end{array}$ & $\begin{array}{l}\text { Effects of firms' } \\
\text { characteristics on } \\
\text { financial } \\
\text { performance of } \\
\text { listed insurance } \\
\text { companies in } \\
\text { Nigeria }\end{array}$ & $\begin{array}{l}\text { The research design adopted for the study } \\
\text { was the ex-post facto design. The census } \\
\text { sampling technique was adopted and } \\
\text { secondary data obtained from annual } \\
\text { reports and accounts of the companies } \\
\text { were used. }\end{array}$ & $\begin{array}{l}\text { The robust regression results indicated } \\
\text { that parameter estimated for liquidity } \\
\text { and age were found to have significant } \\
\text { negative impact on profitability of } \\
\text { Nigerian insurance companies at } 1 \% \\
\text { level of significance. Size was found to } \\
\text { have significant positive impact on the } \\
\text { profitability of Nigerian Insurance } \\
\text { Companies at } 1 \% \text { level of significance }\end{array}$ \\
\hline 16. & $\begin{array}{l}\text { Ajibola, } \\
\text { Wisdom and } \\
\text { Qudus [18] }\end{array}$ & $\begin{array}{l}\text { Capital structure } \\
\text { and financial } \\
\text { performance of } \\
\text { listed manufacturing } \\
\text { firms in Nigeria }\end{array}$ & $\begin{array}{l}\text { The longitudinal design was considered } \\
\text { suitable for the study, and data and } \\
\text { variables were based within a selected } \\
\text { period of time. The data were obtained } \\
\text { from published reports of the listed } \\
\text { manufacturing companies for each of the } \\
\text { periods from 2005-2014 }\end{array}$ & $\begin{array}{l}\text { The findings of the panel ordinary least } \\
\text { square showed that a positive } \\
\text { statistically significant relationship exist } \\
\text { between Long Term Debt Ratio } \\
\text { (LTDR), Total Debt Ratio (TDR) and } \\
\text { Return on Equity (ROE), while a } \\
\text { positive statistically insignificant } \\
\text { relationship was observed between } \\
\text { Short-Term Debt (STD) ratio and ROE. }\end{array}$ \\
\hline 17 & Muraina [23] & $\begin{array}{l}\text { Determinants of } \\
\text { listed Deposit } \\
\text { money banks' } \\
\text { profitability in } \\
\text { Nigeria }\end{array}$ & $\begin{array}{l}\text { The researcher used correlational research } \\
\text { design to examine the determinants of } \\
\text { profitability of the Deposit Money Banks } \\
\text { in Nigeria. Secondary data obtained from } \\
\text { the listed deposit money bank's financial } \\
\text { statements were analysed. }\end{array}$ & $\begin{array}{l}\text { The results of the study showed that } \\
\text { internal factors had significant } \\
\text { influence on deposits money banks' } \\
\text { profitability over the period of the } \\
\text { study. Capital adequacy had a positive } \\
\text { and significant relationship with } \\
\text { profitability while credit risk had a } \\
\text { negative and significant relationship } \\
\text { with banks' profitability during the } \\
\text { period of study. }\end{array}$ \\
\hline 18 & $\begin{array}{l}\text { Onyekwelu, } \\
\text { Nnadi and } \\
\text { Iyidiobi [13] }\end{array}$ & $\begin{array}{l}\text { Evaluation of } \\
\text { Firms' Corporate } \\
\text { financial indicators } \\
\text { and operational } \\
\text { performance of } \\
\text { selected firms in } \\
\text { Nigeria. }\end{array}$ & $\begin{array}{l}\text { The researchers adopted the ex-post facto } \\
\text { research design. Two oil and gas firms } \\
\text { were selected as sample size for the study. } \\
\text { Multiple regressions were used for } \\
\text { analysis of data. }\end{array}$ & $\begin{array}{l}\text { Results indicated that both firms' size } \\
\text { and profit margin had negative and } \\
\text { insignificant effect on ROA of the } \\
\text { companies studied. }\end{array}$ \\
\hline 19 & $\begin{array}{l}\text { Matar and } \\
\text { Eneizan [30] }\end{array}$ & $\begin{array}{l}\text { Determinants of } \\
\text { financial } \\
\text { performance in the } \\
\text { industrial firms: } \\
\text { evidence from } \\
\text { Jordan }\end{array}$ & $\begin{array}{l}\text { The ex-post facto method of design was } \\
\text { adopted - secondary data were used as } \\
\text { gathered from Amman Stock Exchange } \\
\text { annual publication - Financial statement } \\
\text { of industrial companies listed in Amman } \\
\text { Stock Exchange for the period 2005-2015. } \\
\text { The sample consisted of twenty three (23) } \\
\text { industrial companies }\end{array}$ & $\begin{array}{l}\text { The results showed that the variables of } \\
\text { liquidity, profitability and revenues are } \\
\text { positively related with the ROA and the } \\
\text { variables of leverage and firm size are } \\
\text { negatively related with ROA. In } \\
\text { addition, the regression results show } \\
\text { that all variables are significant in the } \\
\text { model. }\end{array}$ \\
\hline
\end{tabular}

Source: Researchers' Compilation, 2020. 


\section{Gap in the Empirical literature}

From the review of empirical studies on Table 1 , from both locally and internationally conducted researches, none of these studies examined the determinant of financial performance of the listed oil and gas companies in Nigeria considering both the internal and external variables, which this present study considered. This study therefore adds to the literature on empirical study considering both internal and external determinants of financial performance of oil and gas

\section{Methodology}

The researchers adopt the ex-post facto research design for the study. The adoption of this research design was to enable the researchers to examine the influence of the selected internal and external variables on the financial performance of the listed oil and gas companies in Nigeria. As at 31st
December, 2018, there were a total of twelve (12) listed oil and gas companies on the floor of the Nigerian Stock Exchange (NSE) from which six (6) were purposively selected for this study. The selected companies are those with complete data required for the investigation and longest valid date of incorporation. Thus, data for the study were gathered from published annual financial reports and the Central Bank of Nigeria $(\mathrm{CBN})$ for Real Gross Domestic product (RGDP) and inflation rates. The six (6) selected companies are Mobil Plc, Etena Plc, Forte oil PLC, MRS Oil Nig. Plc, Oando Plc and Total Nig. Plc.

Secondary data for the period 2012 to 2018 were collected for the study; hence time series data is used for the study. The measurement and a priori expectation for each of the selected independence variables on the dependent variable is presented on the Table 2 .

Table-2: Variables of the study and $A$ priori Expectation

\begin{tabular}{|l|l|l|l|l|}
\hline S/No & Variable & Abbre. & Measurement & Expected sign \\
\hline 1 & Financial performance (dependent) & ROA & Profit after tax/Total Assets & \\
\hline 2 & Capital Structure (independent) & CAS & Total debts/Total equity & + \\
\hline 3 & Liquidity (independent) & LG & Current assets/Current liquidity & + \\
\hline 4 & Size (independent) & SZ & Logarithm of Total assets & + \\
\hline 5 & Age (independent) & AG & Year or incorporation & + \\
\hline 6 & Sales Revenue Growth (independent) & SRG & Trend Analysis of Revenue & + \\
\hline 7 & Profit Margin (independent) & PM & Profit after tax/Sales Revenue & + \\
\hline 8 & Tangibility (independent) & TAN & PPE/Total Assets & + \\
\hline 9 & Inflation Rate (control) & IFR & Annual rate of inflation & - \\
\hline 10 & Growth Rate of Real GDP (control) & RGDP & GDPn - GDP(n-1)/ GDP(n-1) & + \\
\hline
\end{tabular}

Source: Researchers' Compilation.

From the above, the model for this study is stated as follows:

$\mathrm{ROA}=\beta \mathrm{o}+\beta_{1} \mathrm{CAS}+\beta_{2} \mathrm{LQ}+\beta_{3} \mathrm{SZ}+\beta_{4} \mathrm{AG}+$ $\beta_{5} \mathrm{SRG}+\beta_{6} \mathrm{PM}+\beta_{7} \mathrm{TAN}+\beta_{8} \mathrm{IFR}+\beta_{9} \mathrm{RGDP}+\mathrm{U}$. model I.

The dependent variable is Return on assets (ROA) while the independent variables are: Internal variables - capital structure (CAS), Liquidity (LQ), Size (SZ), Age (AG), Sales Revenue Growth (SRG), Profit Margin (PM) and Tangibility (TAN), external variables - inflation rate (IFR) and Growth Rate of Real Gross Domestic Product (RGDP).

The descriptive statistics, correlation coefficient (R), R - square, Adjusted R - square, t statistics ( $\mathrm{t}$ - stat), variance inflation factor (VIF),
Tolerance, Durbin-Watson (DW) statistics, F - ratio and $\mathrm{P}$ - value from multiple linear regression model results were used to analyze the data collected and to answer the research question at $5 \%$ level of significance.

\section{RESULTS AND FINDINGS}

The results and findings of this study are presented using descriptive statistics, correlation analysis, model summary, ANOVA and regression coefficients.

\section{DESCRIPTIVE ANALYSIS}

Descriptive analysis is carried out using the descriptive statistical values as shown on Table 3. 
Table-3: Descriptive Statistic

\begin{tabular}{|l|l|l|l|l|l|}
\hline Variables & N & Minimum & Maximum & Mean & STD. Deviation \\
\hline ROA & 42 & -36.84 & 13.22 & 2.1752 & 9.30290 \\
\hline CAS & 42 & -830.98 & 715.44 & 51.7276 & 186.82808 \\
\hline LQ & 42 & 72.23 & 178.70 & 107.5860 & 23.29925 \\
\hline SZ & 42 & 7.23 & 8.46 & 7.8631 & .30366 \\
\hline AG & 42 & 23.00 & 67.00 & 48.6667 & 12.39132 \\
\hline SRG & 42 & -100.00 & 141.66 & 7.3905 & 36.66406 \\
\hline PM & 42 & -720.24 & 59.51 & -45.2812 & 182.94791 \\
\hline TAN & 42 & .18 & 296.12 & 25.2144 & 44.19072 \\
\hline IFR & 42 & 8.00 & 18.55 & 11.8443 & 3.67734 \\
\hline RDGP & 42 & -1.58 & 6.22 & 2.8371 & 2.56071 \\
\hline Valid N (Listwise) & 42 & & & & \\
\hline
\end{tabular}

Source: Researchers' computation using SPSS version 25 .

From Table 3, the ROA has a mean value of 2.18 and standard deviation of 9.30. The CAS has mean value of 51.73 and standard deviation of 183.83. The LQ has a mean value of 107.59 and standard deviation of 23.30. The SZ has mean value of 7.86 and standard deviation of 0.30 . The AG has a mean value of 48.67 and standard deviation of 12.39. The SRG has a mean value of 7.39 and standard deviation of 36.66. The PM has a mean value of -45.28 and standard deviation of 182.95. The TAN has a mean value of 25.21 and standard deviation of 44.19. The IFR has a mean value of 11.84 and standard deviation of 3.68. The RGDP has a mean value of 2.84 and standard deviation of 2.56 . Analysing the range value, the spread indicate a wide variation in the dataset.

\section{Correlation matrix and Test of Multi-collinearity}

Correlation analysis and test of multicollinearity is carried out using correlation matrix.

Table-4: Correlation Matrix and Test of multi-collinearity

\begin{tabular}{|l|l|l|l|l|l|l|l|l|l|l|}
\hline Person Correlation & ROA & CAS & LQ & SZ & AG & SRG & PM & TAN & IFR & RGDP \\
\hline ROA & 1.000 & .144 & .234 & -.564 & .264 & -.039 & .803 & .132 & .053 & -.046 \\
\hline CAS & .144 & 1.000 & .149 & -.187 & .074 & .204 & -.288 & -.020 & .111 & -.074 \\
\hline LQ & .234 & .149 & 1.000 & -.453 & -.224 & .051 & .194 & .192 & .250 & -.239 \\
\hline SZ & -.564 & -.187 & -.453 & 1.000 & .334 & -.065 & -.478 & -.202 & .104 & -.141 \\
\hline AG & .264 & .074 & -.224 & .334 & 1.000 & -.033 & 0.62 & -.001 & .076 & -.111 \\
\hline SRG & -.039 & .204 & .051 & -.065 & -.033 & 1.000 & -.112 & -.029 & -.020 & .055 \\
\hline PM & .803 & -.288 & .194 & -.478 & .062 & -.112 & 1.000 & .150 & -.017 & .044 \\
\hline TAN & .132 & -.020 & .192 & -.202 & -.001 & -.029 & .150 & 1.000 & .103 & -.084 \\
\hline IFR & .053 & .111 & .250 & .104 & .076 & -.020 & -.017 & .133 & 1.000 & -.921 \\
\hline RGDP & -.046 & -.074 & -.293 & -.141 & -.111 & .055 & .044 & -.084 & -.921 & 1.000 \\
\hline N & 42 & 42 & 42 & 42 & 42 & 42 & 42 & 42 & 42 & 42 \\
\hline
\end{tabular}

Source: Researchers' Computation using SPSS version 25.

From the correlation matrix result, there is no multi-collinearity in all the independent variable because they all have correlation coefficient with each independent variable of less than $0.8(80 \%)$.
Model evaluation and Regression Coefficients

The econometric model developed for this was study was stated as:

$\mathrm{ROA}=\beta_{\mathrm{o}}+\beta_{1} \mathrm{CAS}+\beta_{2} \mathrm{LQ}+\beta_{3} \mathrm{SZ}+\beta_{4} \mathrm{AG}+\beta_{5} \mathrm{SRG}+$ $\beta_{6} \mathrm{PM}+\beta_{7} \mathrm{TAN}+\beta_{8} \mathrm{IFR}+\beta_{9} \mathrm{RGDP}+\mu$

$\mathrm{ROA}=63.852+0.299 \mathrm{CAS}-0.26 \mathrm{LQ}-.266 \mathrm{SZ}+.267 \mathrm{AG}-$ $016 \mathrm{SRG}+0.758 \mathrm{PM}-.27 \mathrm{TAN}-.109 \mathrm{IFR}-.172 \mathrm{RGDP}$

Table-5: Regression Coefficients

\begin{tabular}{|c|c|c|c|c|c|c|}
\hline \multirow{2}{*}{ Model 1} & \multirow{2}{*}{$\begin{array}{c}\text { Standardized Coefficient } \\
\text { Beta }\end{array}$} & \multirow[t]{2}{*}{ Std. Error } & \multirow[t]{2}{*}{$\mathbf{t}$} & \multirow[t]{2}{*}{ Sig. } & \multicolumn{2}{|c|}{ Collinearity Statistic } \\
\hline & & & & & Tolerance & VIF \\
\hline (Constant) & 63.852 & 25.231 & 2.531 & 0.16 & & \\
\hline CAS & .299 & .004 & 3.756 & .001 & .664 & 1.505 \\
\hline LQ & -0.26 & .031 & -.329 & .744 & .6882 & 1.467 \\
\hline $\mathrm{SZ}$ & -.266 & 3.077 & -2.650 & .012 & .418 & 2.392 \\
\hline $\mathrm{AG}$ & .267 & .057 & 3.489 & .001 & .728 & 1.383 \\
\hline SRG & -.016 & .017 & -.239 & .813 & .941 & 1.063 \\
\hline PM & .758 & .005 & 8.440 & .000 & .523 & 1.911 \\
\hline TAN & -.027 & .014 & -.399 & .693 & .919 & 1.088 \\
\hline IFR & -.109 & .430 & -.639 & .528 & .146 & 6.861 \\
\hline RGDP & -.172 & .620 & -1.009 & .321 & .145 & 6.899 \\
\hline
\end{tabular}

Source: Researchers' computation (2020), using SPSS version 25 
The results, CAS $(\beta=0.299$ and $\mathrm{PM}<0.05) ; \mathrm{SZ}$ $(\beta=0.266$, P-value $<0.05) ; \mathrm{AG}(\beta=0.267$, $\mathrm{P}$-value $<0.05)$ and PM $(\beta=0.758, P$-value $<0.05)$ were statistically significant on the model. The Variance Inflation Factor (VIF) and the tolerance showed that there was no multicollinearity in each of the independent variables. The
D-W statistic of 1.916 showed that there is no first order autocorrelation in the model.

The other regression results are shown on the tables that follow:

Table-6: Model Summary ${ }^{\mathrm{b}}$

\begin{tabular}{|l|l|l|l|l|l|}
\hline Model & R & R-square & Adj. R.square & Std. error of the Estimate & Durbin-Watson \\
\hline 1 & $.930^{\mathrm{a}}$ & .865 & .827 & 3.86841 & 1.906 \\
\hline
\end{tabular}

a. Predictors; (Constant), RGDP, PM, SRG, AG, TAN, CAS, LQ, SZ, IFR

b. Dependent variable: ROA

Table-7: ANOVA ${ }^{a}$

\begin{tabular}{|l|l|r|l|l|l|l|}
\hline Model & & Sum of squares & df & Mean squares & F & Sig. \\
\hline 1 & Regression & 3069.438 & 9 & 341.049 & 22.790 & $.000^{\mathrm{b}}$ \\
& Residual & 478.867 & 32 & 14.965 & & \\
& Total & 3548.305 & 41 & & & \\
\hline
\end{tabular}

a. Dependent variable: ROA

b. Predictors; (Constant), RGDP, PM, SRG, AG, TAN, CAS, LQ, SZ, IFR

From Table 6, the R-square showed that $86.5 \%$ variations in ROA was explained by the influence of internal and external variables (CAS, LQ, SZ, AG, SRG, PM, TAN, IFR and RGDP) and the adjusted Rsquare showed that exact $82.70 \%$ variations in ROA was explained by the influence of the variables captured in the model. The p-value of F-ratio indicated that the $\mathrm{R}^{2}$ was significant. The F-value of 22.79 , which is significant at $5 \%$ level $(\mathrm{P}=0.000)$ means the model is robust and suitable for policy formulation.

\section{Discussion of the Findings}

From the results of the analyses, the variables (CAS, LQ, SZ, AG, SRG, PM, TAN, IFR and RGDP) had a significant influence on the financial performance (ROA) of the listed oil and gas companies in Nigeria when treated jointly with $\mathrm{R}^{2}$ value $(86.5 \%)$. This study is consistent with Olaoye and Olarewaju [8].

In the test of the model, CAS, SZ, AG and PM were found to be significant. CAS showed a positive relationship with financial performance (ROA). This is consistent with Muraina [23] who conducted a study on determinants of listed deposit money banks' profitability in Nigeria and found that internal factors had significantly influenced the deposit money profitability over the study period. The study findings did not support the result of Enekwe et al. [6] that found Debt-Equity ratio had negative effect on ROA of the quoted Pharmaceutical companies in Nigeria.

Size (SZ) indicated a negative relationship with financial performance (ROA). This was in line with the findings of Hassan and Farouk [26] who conducted a study on firm attributes and earnings quality of listed oil and gas companies in Nigeria, but contrary with the findings of Abubakar, et al. [9] who found the size of company asset was a determinant of the company's performance among listed insurance companies in Nigeria.

Age (AG) showed a positive relationship with Return on Asset (ROA) and profit margin (PM) indicated a positive relationship with financial performance. This finding was not in line with Onyekwelu et al. [13] who conducted a study on evaluation of firms' corporate financial indicators and operational performance of selected firms in Nigeria and found profit margin had negative and insignificant effect on ROA of the companies studied.

Size (SZ) deviated from the a priori expectation, which we stated as positive. From the analysis, SZ indicated negative and significant relationship with the financial performance of the listed oil and gas companies in Nigeria. This is attributed to the fact that the total assets of the listed oil and gas companies accumulated is at optimum level that it cannot affect the financial performance positively.

The two macroeconomic indicators (inflation rate and growth rate of GDP) indicated positive but insignificant impact on the financial performance of oil and gas companies. Among the internal variables' LQ, SRG and TAN indicated a negative and insignificant impact on financial performance of the listed oil and gas companies in Nigeria. LQ, SRG, TAN and RGDP deviated from the a priori expectation.

\section{Conclusion And Recommendations}

This study was conducted to ascertain financial performance determinants at the Nigerian oil and gas sector. Specifically, the internal and external variables were investigated on their impact on the financial performance. From the analysis and findings, the capital structure, profit margin, size and age had a 
significant impact on the financial performance of the listed oil and gas companies in Nigeria, and the internal and external variables had jointly significant influence on the dependent variable of study. The following recommendations are made:

i) The liquidity of the oil and gas companies should be effectively managed by reducing excessive current assets in the portfolio of assets.

ii) The total assets should be reduced by either disposing some of the investments or by not acquiring more assets but without adversely affecting operations.

iii) Debt capital should be acquired more by the listed oil and gas companies through issuance of debt instruments such as debentures.

\section{REFERENCES}

1. Effiong, J. (2010). Oil and Gas Industry in Nigeria: The Paradox of the block Gold. Research in Social Problems and Public Policy, 18:323-350.

2. KPMG. (2014). Nigeria's Oil and Gas Industry Brief. KPMG International Cooperative "KPMG International", 248p.

3. Adelegan, A. E. (2017). Oil and Gas Sector Law reform and its implications for economic development in Nigeria. International Journal of Development and Economic Sustainability, 5(3):24-31.

4. Ani, W. U., Ugwunta, D. O., Ezeudu, I. J., \& Ugwuanyi, G. O. (2012). An empirical assessment of the determinants of bank profitability in Nigeria: Bank characteristics Panel Evidence. Journal of Accounting and Taxation, 4(3):38-43.

5. Mirza, S. A., \& Javed, A. (2013). Determinants of financial performance of a firm: Case of Pakistan Stock Market. Journal of Economics and International Finance, 5(2): 43-52.

6. Enekwe, C. I., Agu, C. I., \& Eziedo, K. N. (2014). The effect of financial leverage on financial performance: evidence of quoted Pharmaceutical Companies in Nigeria. Journal of Economics and Finance, 5(3):17-25.

7. Ogunbiyi, S. S. and Ihejirika, P. (2014). Determinants of deposit money banks profitability in Nigeria. Arabian Journal of Business Management Research, 4(3):127-141.

8. Olaoye, F. O., \& Olarewaju, O. M. (2015). Determinants of deposit money banks' profitability in Nigeria. Kuwait chapter of Arabian Journal of Business and Management Review, 4(9):11-18.

9. Abubakar, A., Sulaiman, L., \& Haruna, U. (2018). Effect of firms characteristics on financial performance of listed insurance companies in Nigeria. African Journal of History and Archaeology, 3(1):1-9.

10. Ejike, S. I., \& Agha, N. C. (2018). Impact of operating liquidity on profitability of Pharmaceutical firms in Nigeria. International
Journal of Academic Research in Accounting, Finance and Management Sciences, 8(3):73-82.

11. Chai, N. (2009). Sustainability performance evaluation system in government. A Balanced Scorecard approach towards sustainable development. London: Springer, 148p.

12. Owolabi, S. A., \& Obida, S. S. (2012). Liquidity management and corporate profitability. Case study of selected manufacturing companies listed on the Nigerian Stock Exchange. Business Management Dynamics, 2:10-25.

13. Onyekwelu, U. L., Nnadi, C. S., \& Iyidiobi, F. (2018). Evaluation of firms' corporate financial indicators and operational performance of selected firms in Nigeria. Research Journal of Finance and Accountability, 9(4):20-29.

14. Yadav, S. K., Kapor, R., \& Dhaigude, A. S. (2016). Financial performance ranking of oil anf gas companied in India using Topsis method. International Journal of Business Excellence, 14(6):4463-4473

15. Akeem, L. B., Edwin, T. K., Kiyanjul, M. W., \& Kayode, A. M. (2014). Effects of Capital Structure on Firms Performance: Empirical study of manufacturing companies in Nigeria. Journal of Finance and Investment Analysis, 3(4):39-57.

16. Cekrezi, A. (2015). Determinants of financial performance of the Insurance Companies: A Case of Albania. International Journal of Economics, Commerce and Management, 3(4):1-10.

17. Adesina, J. B., Nwidobie, B. M., \& Adesina, O. I. (2015). Capital Structure and Financial performance in Nigeria. International Journal of Business and Social Research, 5(2):21-31.

18. Ajibola, A., Wisdom, O., \& Qudus, O. L. (2018). Capital Structure and Financial Performance of listed manufacturing firms in Nigeria. Journal of Research in International Business and Management, 5(1):81-89.

19. Omondi, M. M., \& Muturi, W. (2013). Factors affecting the financial performance of listed companies at the Nairobi Securities Exchange in Kenya. Research Journal of Finance and Accounting, 4(15):99-104.

20. Wanjugu, M. J. (2014). The determinants of financial performance in General Insurance Companies in Nairobo: Kenya. Journal of Commerce, Business and economic Studies, 7(2): 141-154

21. Grace, O. N., Ann, D. N., \& Onodugo, V. (2016). Liquidity management and profit performance of Pharmaceutical manufacturing firms listed in Nigeria Stock Exchange. International Journal of Management Sciences and Business Research, 5(7):1013.

22. Ahuja, N., Sharma, A. R., \& Baylin, S. B. (2016). Epigenetic therapeutics: a new weapon in the war against cancer. Annual review of medicine, 67, 7389. 
23. Muraina, S. A. (2018). Determinants of listed deposit money banks profitability in Nigeria. International Journal of Finance and Banking Research, 4(3): 40-56.

24. Ludwig, Von Bertanlanff. (1956). General System Theory, Canada: University of Alberta Edmonton, 347.

25. Abbas, A., Bashir, Z., Manzoor, S., \& Akram, M. N. (2013). Determinants of firm's financial performance: an empirical study on textile sector of Pakistan. Business and Economic Research, 3(2), 76.

26. Hassan, S. U., \& Farouk, M. A. (2014). Firm attributes and earnings quality of listed oil and gas companies in Nigeria. Research Journal of Finance and Accounting, 5(178):10-17.

27. Adeusi, S. O., Kolapo, F. T., \& Aluko, A. O. (2014). Determinants of Commercial Banks'
Profitability: Panel evidence from Nigeria. International Journal of Economics, Commerce and Management, 7(2):1-18.

28. Iskakov, S., \& Yilmaz, N. K. (2015). Performance evaluation of major integrated oil and gas companies. International Journal of Economics, Commerce and Management, 3(6):332-361.

29. Nwaolisa, E. F., \& Chijindu, A. A. (2016). The Influence of financial structure on profitability with Special reference to oil and gas firms in Nigeria. Advances in Research, 5(2):1-17.

30. Matar, A., \& Eneizan, B. M. (2018). Determinants of financial performance in the Industrial firms: Evidence from Jordan. Asian Journal of Agricultural Extension, Economics and Sociology, 22(1): 1-10. 